\title{
Economic Contribution of Language Industry in China
}

\author{
Wenli Tang* \\ School of Foreign Studies \\ Weinan Normal University, \\ Weinan, China \\ sherrytang67@163.com
}

\begin{abstract}
Based on previous findings pertinent to language economics, the paper deals with the boundary and economic statistics of China language industry from the perspective of its economic contribution. First, it looks at the boundary of language industry. Then, it proceeds to investigate the economic values of language industry. Finally, the paper estimates the output value of China language industry in $\mathbf{2 0 1 0}$. The study is expected to bear relevance for analyzing language economy in an objective and systematic fashion.
\end{abstract}

Keywords-Boundary of language industry; Economic value; Economic contribution; Output value

\section{INTRODUCTION}

Currently, people from different countries have reached a consensus on the economic value of language. Studies on Language Economics as a field of research started to emerge in the mid 1960s. In 1965, American economist Jacob Marschack put forward the notion of Language Economics in his paper entitled "Economics of Language" [1]. Though on the fringes of economics, the issue as a new interdisplinary subject has gained extensive attention among economists and yielded a huge bulk of research literature concerning language planning, language service and language industry etc. [2][3]. A glance back at the previous research on language industry raises further questions as follows: What is the boundary of language industry? What role does language industry play in socioeconomic development and the advancement of human civilization? And to what extent has language industry contributed to economy? These questions are addressed in the present study through recourse to theoretical justification and case-driven analysis so as to shed light on the understanding of the values of language industry and its contribution to economy.

\section{LANGUAGE InDUSTRY: DEFINITION AND BOUNDARY}

The two terms "language industry" and "language service industry" are used by the EU Translation Bureau and American Consulting Companies respectively, referring to the same industry with profit-making as its goal. The Study on the size of the language industry in the EU issued by the EU Translation Bureau in 2009 and Study on the Development of China's Language Industry: 2012 released by Chinese Translators' Association both define "language industry" in a much narrow sense confining this industry basically to translation services.
According to the Language Technology Center in Germany, the language industry, as stated in Study on the size of the language industry in the EU, deals with such areas as language training, translating, interpreting, language tools, subtitle translating and dubbing, software localization and network globalization, conference organizing and consulting. An observation of this report reveals that it fails to categorize the language industry thoroughly. For example, it doesn't involve the publishing of language books, neither does it mention language creation industry exemplified by font design, naming etc. What should be noted is that language training and translating (including interpreting) are the two main parts that make up the language industry. Therefore, "language industry" is termed as an industry of translation services in a narrow sense, even with the mentioning of language training, which for the most part aims at improving learners' translation competence.

In China, the past several decades has witnessed the demand for and practice of language service, and the term "language service industry" was put forward by Chinese Translators' Association executive vice President Guo Xiaoyong, who, in his keynote speech for the conference China's Language Service Industry: Problems and Solutions on September, 26 in 2010, started to look at language service industry as a new rising industry that includes translating and localizing service, research of language technology tools, language teaching and training, language consulting. The language service industry goes far beyond the traditional translating industry, constituting an integral part of global industry chain.

Two years later, Chinese Translators' Association released Study on the Development of China's Language Industry:2012, in which it classified the organizations and institutions engaged in language service industry into three interrelated layers: the core layer, the relevant layer, and the supporting layer.

The core layer consists of institutions that provide information transformation service, technology development, translation training and consulting service, including translation companies, translation software research and development companies, language training schools and multi-lingual consulting firms etc. The relevant layer comprises organizations and establishments, whose work depends partially on information transformation, such as foreign affairs publicity departments, state administration of press and 
publication departments, large transnational enterprises and tourism industry, trade industry etc. The supporting layer actually refers to government sectors and enterprises that are supportive of language service. As can be seen, language service industry, if defined in a narrow sense, only emphasizes the core layer. The numbers of language service enterprises in China by the end of 2011 are listed in the following table [4].

TABLE I. THE NUMBERS OF LANGUAGE SERVICE ENTERPRISES IN CHINA BY THE END OF 2011

\begin{tabular}{|c|c|c|}
\hline Scope of Business & $\begin{array}{l}\text { Number of } \\
\text { Enterprises }\end{array}$ & Notes \\
\hline Translating & 37130 & \multirow{4}{*}{$\begin{array}{l}\text { The number of } \\
\text { employees in language } \\
\text { industry reached } 1.19 \\
\text { million in } 2011 \text {, among } \\
\text { which there were } 0.64 \\
\text { million translators and } \\
\text { interpreters. The output } \\
\text { value amounted to } \\
157.6 \text { billion yuan. }\end{array}$} \\
\hline $\begin{array}{lr}\text { Translation } & \text { and } \\
\text { interpretation } & \text { service, } \\
\text { website internationalization, } \\
\text { localization service, multi- } \\
\text { lingual service }\end{array}$ & 29372 & \\
\hline $\begin{array}{lr}\text { Translation } & \text { software } \\
\text { research and development, } \\
\text { machine translation, } \\
\text { translation aids, language } \\
\text { technology, multi-lingual } \\
\text { information processing }\end{array}$ & 54 & \\
\hline $\begin{array}{l}\text { Translation training, multi- } \\
\text { lingual consulting }\end{array}$ & 278 & \\
\hline
\end{tabular}

Table I generally looks at language industry in its narrow sense. In terms of scope of business, the table basically takes the translation industry as the main body and hardly examines other language-related industries. The language training it lists is also limited to translation training. Obviously, it fails to investigate language publishing, language testing, and other forms of language training, neither does it probe into language market aiming at improving native language competence. Therefore, the table fails to provide all aspects of the language industry that supplies language products.

\section{LANGUAGE INDUSTRY: ECONOMIC VALUE}

Viewed from economic theory, language itself is a kind of human capital, and second (or foreign) language can be a profitable investment, in particular when employers reward them. As Grin puts it, “At the micro level, a person's language skills may lead to wage rate differences that reward those skills. At the macro level, the demographic size of a language community is likely to boost total demand for languagespecific goods and services consumed by that community" [2]. In the ensuing section, the economic value of language industry will be examined through examples of the two great economic contributor to GDP-language training and translation service.

\section{A. The Explicit Economic Value of Professional Language Service}

Professional language service is highly marketized, with its economic value getting enough attention in the field of academia. Language training in particular has been extensively studied, and statistics constantly renewed. With the acceleration of globalization nowadays, China has become a huge market for English language training. A growing number of training schools have been established since late 1980s, contributing considerably to gross domestic output (GDP).
Statistics show that eight educational brands including New Oriental, Xue'ersi and Xueda have all listed on the New York Stock Exchange. These language training companies had a total revenue of $\$ 1.8$ billion in 2012, with a net profit of $\$ 0.193$ billion. Undoubtedly, language training sector has become a major component with explicit economic value in language industry.

Another great contributor to GDP in language industry is translating and interpreting service. According to China's Translation Industry Report: 2014 released jointly by China Academy of Translation and Chinese Translators' Association, there were 5287 translation companies across the country by the end of 2013. Among the 120 companies being surveyed, 26 companies had an annual revenue between 1 million and 2 million yuan, 16 companies reached an annual income between 2 million and 5 million yuan, and 10 companies between 5 million and 10 million yuan. The number of companies with yearly revenue above 10 million yuan hit a record of 29 , accounting for $24 \%$ of the companies surveyed. It is estimated that the potential output value of China's translation market could increase to 1000 billion yuan [5] [6].

\section{B. The Explicit Economic Value of Foreign Language Service}

Apart from professional language service, some industries, such as tourism industry and trade industry, are also characterized by foreign language service. Though not as marketized and benefit quantified as professional language service, this kind of foreign language service has been given enough attention by relevant industries, and effective measures have been taken to bring its economic value into full play. Take tourism industry for example, tourism employees around the world attach more importance to their foreign language proficiencies so as to promote the development of tourism industry. Another case in point is trade industry. Yiwu small commodity city in Zhejiang Province launched bilingual voice announcement service on buses. And many shop signs around Yiwu city are written in foreign languages including Chinese, English, Korean and Arabic. Besides, the website of China Yiwu International Commodities Fair is presented in more than 10 languages, such as Chinese, English, French, Russian, Arabic, Spanish, Japanese, Korean, German etc. to boost sales [7].

\section{ECONOMIC CONTRIBUTION OF LANGUAGE INDUSTRY IN China: A Case Study Of The OutPut Value In 2010}

Statistics production is a key factor in estimating the output value of language industry. Although the boundary of language industry has been discussed in the previous section, the difficulties in producing accurate statistics still cannot be ignored. Statistics of language teaching and training schools, translation companies are easily accessible, while statistics concerning such institutions as language publishing companies and software research and development companies pose a difficulty. Take language publishing companies for example, even the Commercial Press and Foreign Language Teaching and Research Press are not pure language book publishers, let alone other publishing houses. Likewise, software companies research and develop comprehensive soft wares, with language soft wares forming only a part of their products. Therefore, an 
accurate production of statistics in such areas can be difficult. This calls for the joint efforts of the government, research institutions, private enterprises etc. to set up statistics standards, improve statistics methods and statistics channels. Study on the economic contribution of language industry should aim to provide a comprehensive statistics and analysis rather than focusing on particular areas in this industry.

A case study of the output value of language industry in 2010 is presented in the ensuing section. Statistics are obtained from multiple sources and categorized as follows:

\section{A. Translating and Interpreting}

According to China Language Industry Report: 2012 published by Chinese Translators' Association, the output value of China language industry reached 125 billion yuan in 2010. The scope of investigation is confined to the core layer of language industry.

\section{B. Language Training}

Reports from Baidu Data Center reveal that the output value of language training, mainly foreign language training, is estimated at 30 billion yuan in 2010 .

\section{Language Publishing}

China Publishers Yearbook: 2011 shows that on fixed price, the sales of language books reached 5.74787 billion yuan, and the sales of textbooks 3.168612 billion yuan. If calculated on a $40 \%$ discount, the overall sales can amount to 5.34 billion yuan.

\section{Language Teaching Equipment}

A close look at Study on China's Language Equipment Industry: In-depth Research and Future Development Trend issued by China Commercial Network Industry Research Center reveals that the output value of language teaching equipment in 2010 was estimated at 3 billion yuan.

\section{E. Language Testing}

According to Report on Hanyu Shuiping Kaoshi (HSK) by Zhang Jijun, the number of IELTS candidates and TOEFL candidates in 2010 reached 0.3 million and 0.2 repectively. The total examination fee of these two kinds of examinations amounted to 0.75 billion yuan, with the average examination fee being 1,500. Besides, the number of HSK candidates was estimated at 0.12 million. With 350 yuan examination fee for each candidate, the HSK contributed 420 million yuan to the economy. Furthermore, other language tests such as CET-4, CET-6, National Proficiency Test of Putonghua level and GRE generated a total revenue of 0.18 billion yuan. As can be seen, language testing in 2010 at least had an output value of one billion yuan.

\section{F. Language Technology}

Language technology involves word processing, voice message processing, language fast record, laser phototypesetting and digital publishing etc.. Given the fact that smart phone users and personal computer users were estimated at over 0.6 billion, the output value of language technology could hit 30 billion yuan.

From the above-mentioned analysis, it can readily be seen that the total output value of China language industry in 2010 reached 192 billion yuan, accounting for 0.47 percent of GDP, which was 40151.28 billion yuan. The statistics, though not flawless, paved the way for future research. It is advisable that certain standards should be established, statistics methods and channels improved so as to produce more accurate statistics.

\section{REFERENCES}

[1] J. Marschak, "Economics of language," Behavioral Science, vol. 10, pp. 135- 140, 1965.

[2] F. Grin, "Language planning and economics," Current Issues in Language Planning, vol. 1, pp. 1-66, 2003.

[3] F. Vaillancourt, "Language and socioeconomic status in Quebec: Measurement, findings, determinants, and policy costs," International Journal of the Sociology of Language, vol. 121, pp. 69-92, 1996.

[4] Chinese Translators' Association, Study on the Development of China's Language Industry: 2012, Retrieved from http://ishare.iask.sina.com.cn/f /37541255.html. on October 14th, 2018.

[5] H.Z. He, "Language industry as a profitable linguistic enterprise: A review on language industry research \& practice," Applied Linguistics, vol. 3, pp. 9-15, 2012.

[6] X.L. Hu, "On the structure, externality and strategic development of language industry," Applied Linguistics, vol. 3, pp. 35-42, 2013.

[7] L.Q. Mao, "On the value of language resources: A case study of the language in use in Yiwu," Journal of Yunnan Normal University, vol. 4, pp. 15-21, 2009. 